\title{
RANĚ STŘEDOVĚKÉ POHŘEBIŠTĚ V CHRUDIMI, DAŠICKÉ ULICI
}

\author{
JAN FROLÍK - JAN MUSIL - PETRA STRÁNSKÁ
}

\begin{abstract}
Abstrakt: Článek zpřistup̌̌uje informaci o nálezu torza řadového pohřebiště (̌̌est hrobů) na severním okraji raně středověké chrudimské sidelni aglomerace. Radiouhlikové datováni hroby zařadilo do 11. až 12. století. Zařazení nálezu do širšich souvislostí Chrudimska a Pardubicka poukázalo na významnou a přetrvávajíci mezeru v obraze raně středověkého osídlení, za kterou lze považovat právě vesnická řadová pohřebiště. Přičinu, proč se je nedaři objevovat, nelze určit.
\end{abstract}

Kličcová slova: raný středověk - radové pohřebiště - vesnické pohřebiště - antropologie - sídlištni struktura-Chrudimsko.

\section{Early medieval burial site in Dašická Street, Chrudim}

\begin{abstract}
This article presents information about the find of the remains of a row burial site (six graves) on the north edge of an early medieval settlement agglomeration in Chrudim. The radiocarbon analysis dated the graves to the 11th and 12th centuries. The placement of the burial site in the broader context of the Chrudim and Pardubice regions confirmed a major and enduring gap in the picture of the early medieval settlement concerning village row burial grounds. The reason why these are so rarely discovered cannot be determined.
\end{abstract}

Key words: early Middle Ages - row burial site - village burial site - anthropology - settlement structure Chrudim region.

\section{1 Úvod}

Malebné východočeské město Chrudim se nalézá na strategicky položené ostrožně, kterou chrání ze tří stran meandr řeky Chrudimky. Město má dlouhou tradici archeologických výzkumů, systematicky je však Chrudim sledována až od 80. let 20. století (Frolík-Sigl 1995; 1998). Od té doby byly na katastru Chrudimi provedeny desítky záchranných výzkumů, které osvětlily počátky osídlení od pravěku do středověku. V souvislosti s projektem modernizace silnice III/34026 v úseku „Chrudim, železniční přejezd - napojení na I/37“ byl v roce 2015 realizován záchranný archeologický výzkum, který přinesl důležité poznatky o pravěkém a raně středověkém osídlení (Musil 2015; 2015a). Výzkum provedlo Regionální muzeum v Chrudimi ve spolupráci s firmou Terra Verita, spol.sr. o. (výkopové a dokumentační práce). Výzkum proběhl ve dvou etapách v dubnu až červenci roku 2015 a bylo při něm objeveno celkem 57 objektů a šest kostrových hrobů. Vyhodnocení uvedených hrobů je předmětem předloženého př́íspěvku.

Zkoumaný úsek se nalézá na severním okraji města Chrudimi (obr. 1:13), při Dašické ulici. Zájmové území leží v nadmořské výšce $257-260 \mathrm{~m}$ n. m. na velmi mírném jižním svahu, který se sklání k asi $0,5 \mathrm{~km}$ vzdálené řece Chrudimce. Jihovýchodním směrem se vypíná výšinná dominanta v podobě hradiště v poloze Na Pumberkách (kóta $300,1 \mathrm{~m}$ n. m.). V prŕímém sousedství zkoumané plochy se nacházejí raně středověká naleziště v poloze U Májova - nal. $45-\mathrm{v}$ k. ú. Chrudim a nal. 19 a 20 zasahující částečně do k. ú. Vestec (označení nalezišt’ podle Frolík-Sigl 1995; 1998).

\section{Metoda archeologického výzkumu}

Hroby byly zkoumány po přirozených uloženinách dle tzv. Harrisovy metody (Harris 1989) a dokumentovány metodou formalizovaného záznamu do kontextových listů pomocí klíčových slov dle upraveného Manuálu Muzea města Londýna (Westman 1994). Souběžně probíhala měřičská, kresebná a fotografická dokumentace. Vybrané části terénní situace byly zdokumentovány fotogrammetricky. 


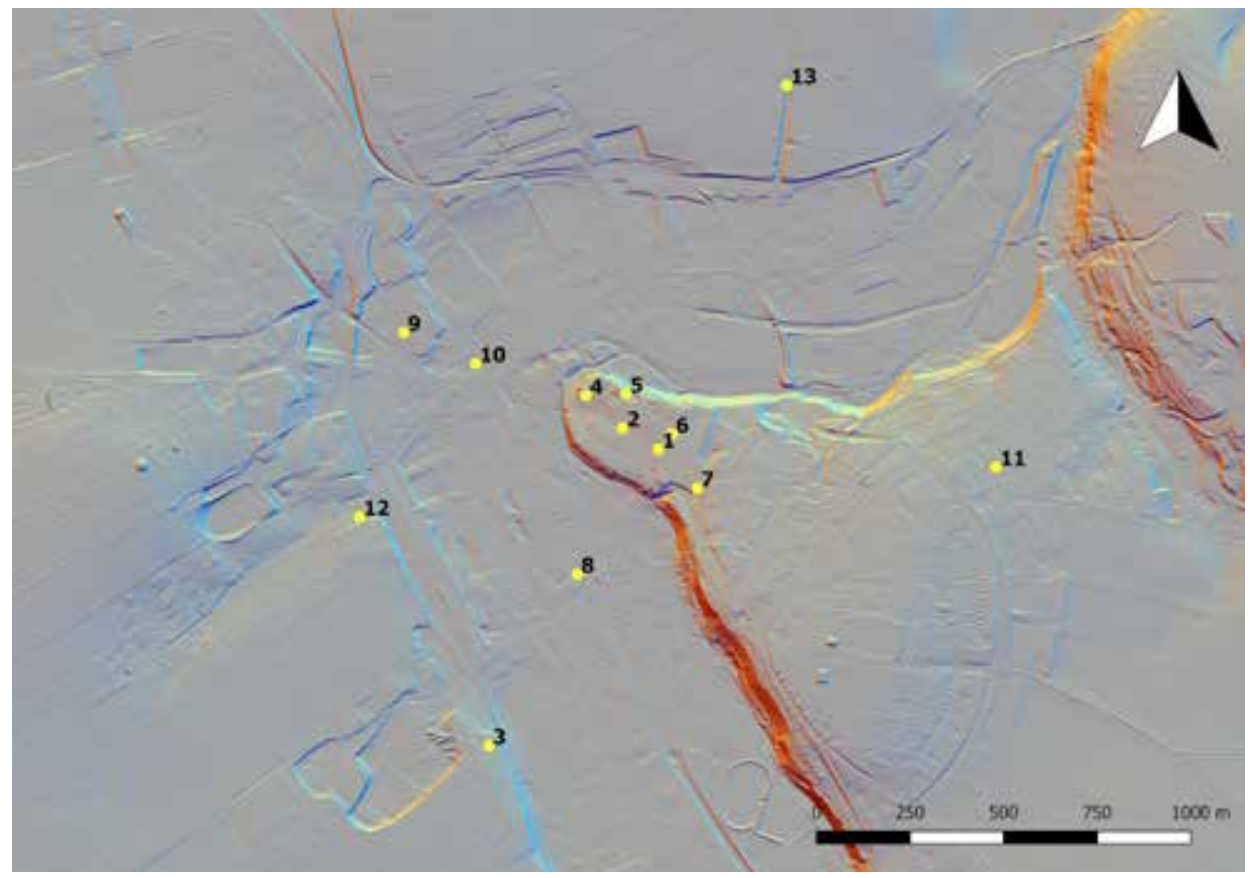

Obr. 1. Chrudim, celkový plán s vyznačením polohy jednotlivých pohřebišt'. Čárkovaně je zvýrazněn obvod hradeb hradiště. 1 - Resselovo nám., hrob 1980; 2 - Resselovo nám., hrob 1956; 3 - pohřebiště u kostela sv. Kříže; 4 - Filištínská, čp. 27/I; 5 - Filištínská, čp. 35/I; 6 - Hradební ul.; 7 - Školní nám.; 8 - Husova ul.; 9 - Čáslavská ul., továrna Wiesner; 10 - Masarykovo nám., Wiesnerova vila; 11 - Topolská ul.; 12 - Jiráskova, čp. 428; 13 - Dašická ul. Podkladová mapa DMR5G (zdroj ČÚZK) vizualizovaná metodou Hillshading for multiple direction. Vytvořeno v programu RVT a QGIS.

Abb. 1. Chrudim, Gesamtplanskizze mit Kennzeichnung der Lage der einzelnen Gräberfelder. Gestrichelt hervorgehoben ist der Wallumfang des Burgwalls. 1 - Platz Resselovo náměstí, Grab 1980; 2 - Platz Resselovo náměstí, Grab 1956; 3 Gräberfeld an der HI. Kreuzkirche; 4 - Filištínská-Str., Nr. 27/I; 5 - Filištínská-Str., Nr. 35/I; 6 - Hradební-Str.; 7 - Platz Školní náměstí; 8 - Husova-Str.; 9 - Čáslavská-Str., Fabrik Wiesner; 10 - Platz Masarykovo náměstí, Villa Wiesner; 11 - Topolská-Str.; 12 - Jiráskova-Str., Nr. 428; 13 - Dašická-Str. Kartenvorlage DMR5G (Quelle Tschechisches Amt für Landesvermessung und Kataster) visualisiert durch Hillshading for multiple direction. Erstellt mit der Software RVT und QGIS.

\section{Popis terénní situace}

Po skrývce a následném začištění zkoumané plochy se objevila následující situace: Do sprašového podloží se zahlubovala série vzájemně se neporušujících objektů různého stáří. Většinu objektů představovaly nejrůznější kůlové jámy (obr. 2). Vzhledem k relativně malému plošnému odkryvu a recentnímu narušení situací (komunikace, kanalizace, inženýrské sítě, stromořadí) nebylo možné rekonstruovat půdorysy a ani je jednoznačně datovat. Nejstaršími zjištěnými objekty byl hliník a zásobní jáma s podebranými stěnami lengyelské kultury stupně IIb.

Neočekávaný byl nález části hrotitého příkopu vymezujícího svým obloukem areál nalézající se pod dnešní komunikací a východně od ní. O asi $20 \mathrm{~m}$ severněji byl objeven na obou stranách ukončený hrotitý př́íkop shodné výplně i hloubky o délce $11,6 \mathrm{~m}$. S největší pravděpodobností představuje předsunutou ochranu vstupu do ohrazeného areálu, který se musel nalézat na jihovýchod od výše zmiňovaného př́ikopu. Z výplně obou př́ikopů byly získány uhlíky a zlomky zvířecích kosti. Z horních partií pocházela patrně sekundárně přemístěná keramika lužické kultury a zlomek mladohradištní keramiky (ten pocházel přímo z místa styku výkopu pro kanalizaci s tímto př́ikopem). Na základě našich současných vědomostí nelze příkop spolehlivě datovat 


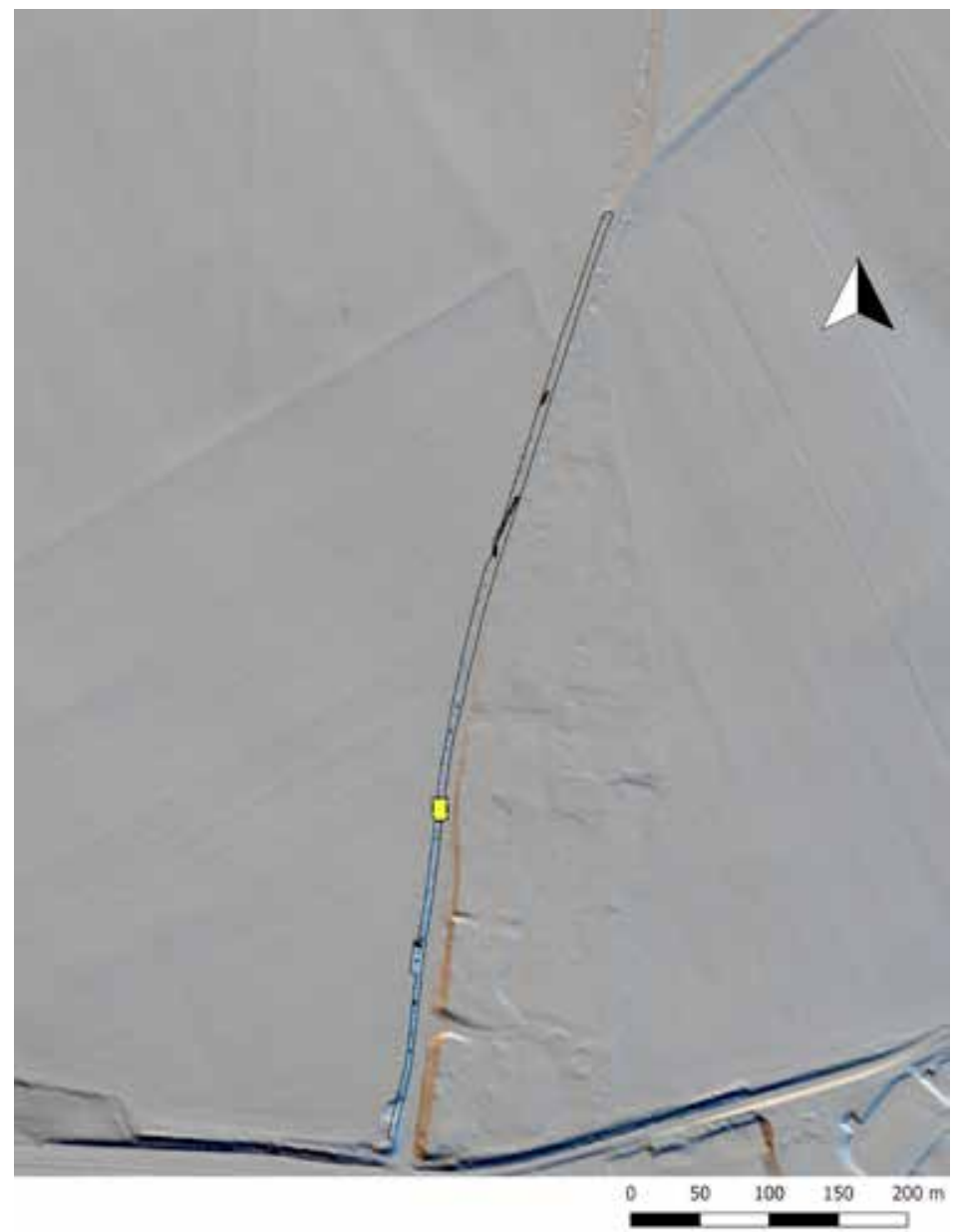

Obr. 2. Chrudim - Dašická ulice, celkový plán zkoumané plochy. Zvýrazněno situování pohřebiště v rámci zkoumané plochy. Podkladová mapa DMR5G (zdroj ČÚZK) vizualizovaná metodou Hillshading for multiple direction. Vytvořeno v programu RVT a QGIS.

Abb. 2. Chrudim - Dašická-Str., Gesamtplanskizze der untersuchten Fläche. Die Lage des Gräberfeldes im Rahmen der untersuchten Fläche wurde hervorgehoben. Kartenvorlage DMR5G (Quelle Amt für Landesvermessung und Kataster) visualisiert durch Hillshading for multiple direction. Erstellt mit der Software RVT und QGIS.

a interpretovat. Překvapením byl objev šesti kostrových hrobů (obr. 3). ${ }^{1}$ Komplikaci při jejich odkryvu představovala poměrně malá hloubka hrobových jam, které se svou výplní de facto neodlišovaly od podorničí. Teprve po opakovaném zvlhčování a přečištování se okraje hrobových jam vyrýsovaly. Antropologické pozůstatky byly vlivem postdepozičních procesů velmi narušeny. Hroby byly uspořádány $\mathrm{v}$ jedné řadě $\mathrm{s}$ rozestupy $1-2 \mathrm{~m}$ mezi jednotlivými hrobovými jámami. Při preparaci hrobové výplně nebyl získán žádný hrobový inventár̆.

1 Na tomto místě je třeba poděkovat zejména Martinu Lantovi a Monice Aulické, bez jejichž pomoci by nebylo možno výzkum úspěšně dokončit. 


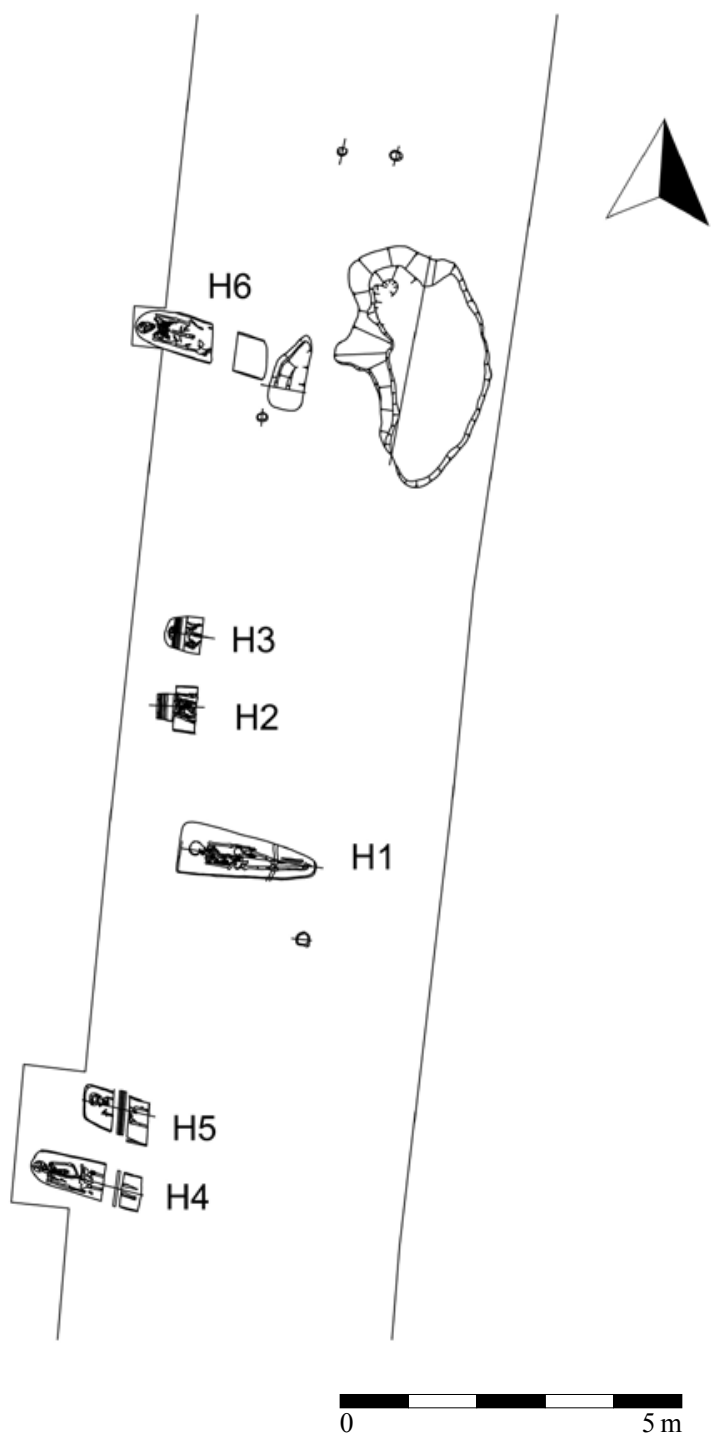

Obr. 3. Chrudim - Dašická ulice, plán pohřebiště. Podle podkladů Terra Verita, s. r. o., upravil J. Musil.

Abb. 3. Chrudim - Dašická-Str., Planskizze des Gräberfeldes. Nach den Unterlagen der Fa. Terra Verita bearbeitet von J. Musil.

\subsection{Popis hrobi̊}

Hrob 1 (obr. 4:1; 5)

Nejzachovalejší ze zkoumaných hrobů. Objeven byl na rozhraní podorničí a podloží. Hrobová jáma byla velmi mělce zahloubena (max. 0,08 m) do podloží. Její tvar byl trapezoidní a zužovala se směrem k nohám, kde byla zaoblena (délka 2,05 m; šířka 0,3 až $0,75 \mathrm{~m}$ ). Zemřelý byl pohřben hlavou k západu v natažené poloze. Pravá ruka směřovala do klína, levá byla natažena podél pánve s prsty pod levým femurem. Lebka byla otočena obličejem k severu. Poloha 


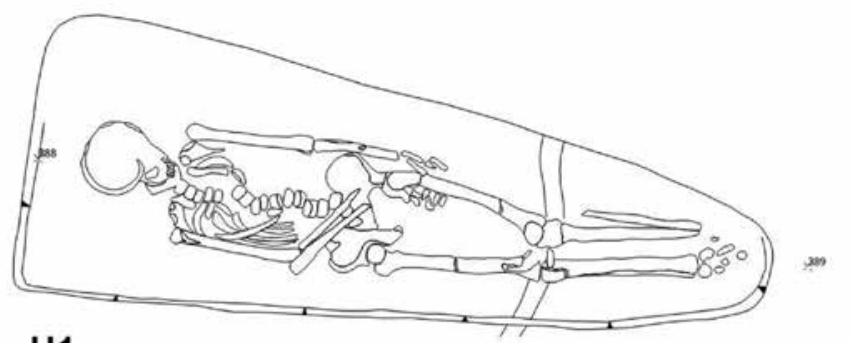

H1
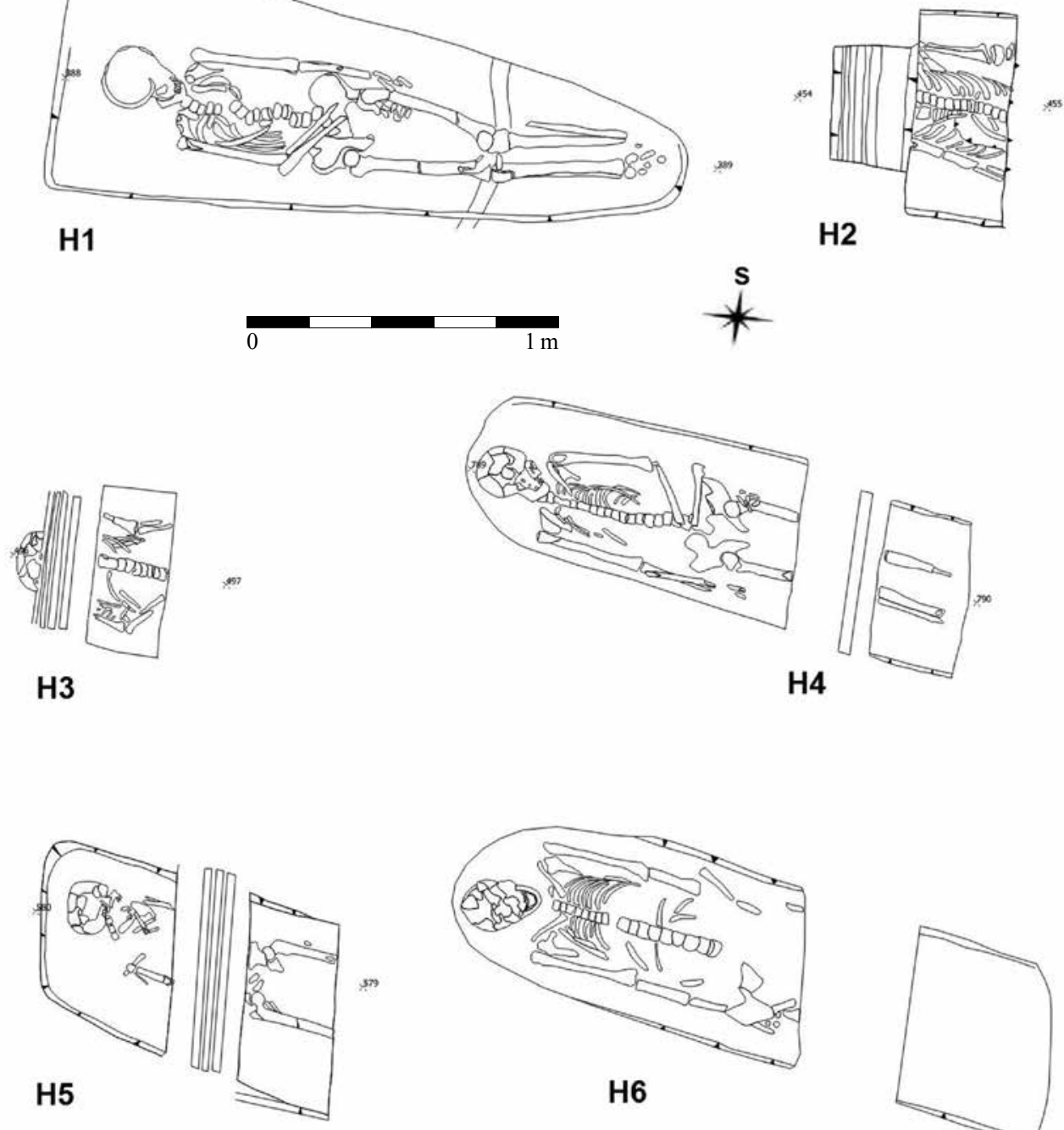

H6

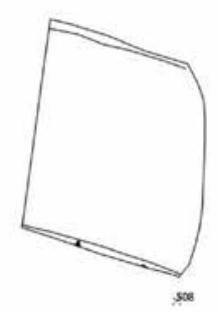

Obr. 4. Chrudim - Dašická ulice, plány jednotlivých hrobů. Podle podkladů Terra Verita, s. r. o., sestavil J. Frolík. Abb. 4. Chrudim - Dašická-Str., Planskizzen der einzelnen Gräber. Nach den Unterlagen der Fa. Terra Verita erstellt von J. Frolík.

distálních konců kostí stehenních a drobných kostí obou nohou naznačuje svázání v kolenou a kotnících nebo těsné ovinutí, např́íklad rubášem. Z kostry se zachovala fragmentární lebka a většina poškozených kostí postkraniálního skeletu. Lebeční fragmenty byly středně- až silnostěnné, se synostozovanými i obliterovanými lebečními švy. Mandibula je se středně vysokým tělem, zaoblenou bradou a vybočeným úhlem ramene. Dochované zuby byly středně silně i silně abradovány. Kosti postkraniálního skeletu byly střední až robustnější stavby, se středně výrazným až výrazným reliéfem svalových úponů a plně přirostlými epifýzami. Pánevní pohlavně determinační znaky jsou mužské. Obě kosti stehenní byly v subtrochanterické oblasti 


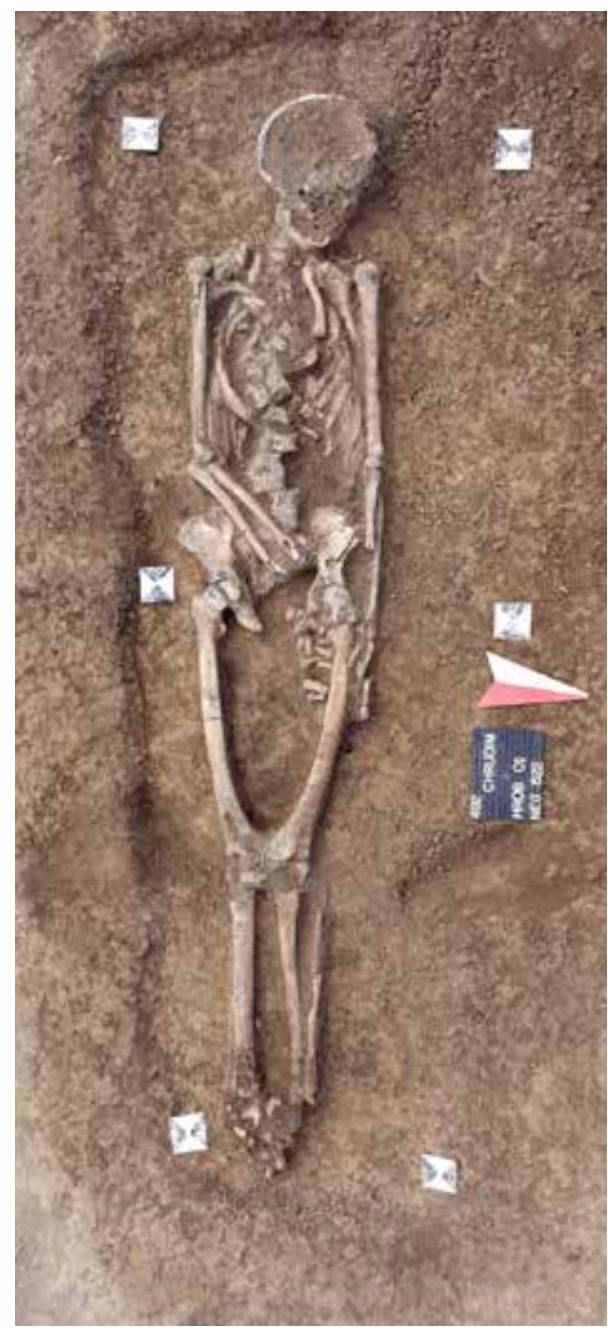

Obr. 5. Chrudim - Dašická ulice, hrob H1. Foto M. Lanta. Abb. 5. Chrudim - Dašická-Str., Grab H1. Foto M. Lanta.

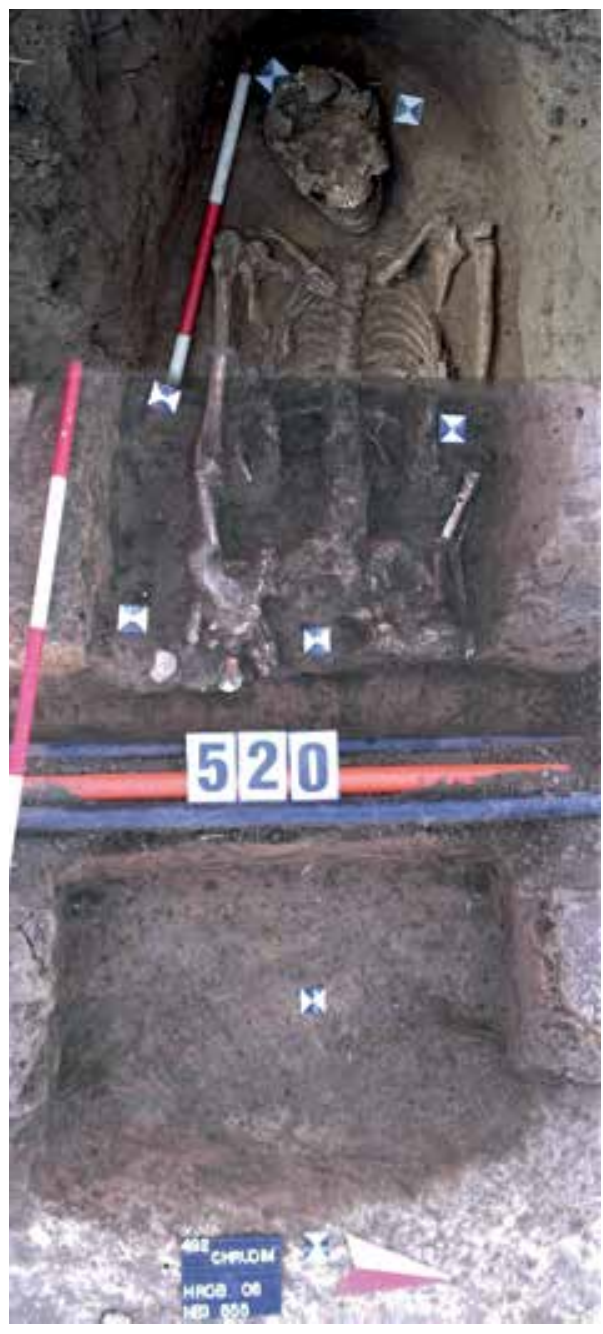

Obr. 6. Chrudim - Dašická ulice, hrob H6. Foto J. Musil. Abb. 6. Chrudim - Dašická-Str., Grab H6. Foto J. Musil.

výrazně předozadně oploštělé, index platymerický spadal do kategorie hyperplatymerie $(\mathrm{dx}-68,4$; sin-64,1). Patologické nálezy: Šest intravitálních ztrát, jeden drobný zubní kaz, výrazná retrakce alveolárních oblouků. Spondylóza II. stupně na krčních obratlích, artrotické změny na obvodu proximálních hlavic obou kostí stehenních. Na obou kostech klíčních výrazná drsnatina pro úpon kostoklavikulárního vazu, výrazné tuberculum conoideum (místo pro ligamentum coracoclaviculare). Na pravé kosti holenní je pokročilá periostitida (obr. 8), periostotické změny také na distálních částech diafýz obou kostí stehenních a na diafýze levé kosti holenní. Závěr: muž, maturus II - senilis (nad 55 let).

Hrob 2 (obr. 4:2)

Torzo hrobu, zjištěna jen malá část hrobové jámy (šiřka $0,75 \mathrm{~m}$, dochovaná délka $0,35 \mathrm{~m}$ ) nepatrně zahloubené do podloží $(0,06 \mathrm{~m})$. Z kostry se dochovala část hrudníku - zlomky kosti 
hrudní, žeber, deset hrudních obratlů, dva bederní a zlomky dlouhých kostí obou horních končetin. Podle toho je možné určit, že zemřelý byl pohřben hlavou k západu. Polohu rukou a nohou nelze určit. Hlava a kostra níže od hrudníku byly odstraněny dvěma recentními výkopy. Zachované kosti jsou středně robustní stavby, s plně přirostlými epifýzami. Patologické nálezy: zhojená zlomenina žebra, artrotické změny na tuberculum costae, spondylartróza na hrudních obratlích. Závěr: neurčitelný jedinec, adultus II+ (nad 35 let).

\section{Hrob 3 (obr. 4:3)}

Torzo hrobu, zjištěna jen malá část hrobové jámy (šířka $0,6 \mathrm{~m}$, dochovaná délka $0,3 \mathrm{~m}$ ) nezahloubené do podloží. Výplň hrobové jámy byla dokumentována v mocnosti až $0,12 \mathrm{~m}$. Z kostry se dochovaly zlomky plochých lebečních kostí, zlomky žeber, obratlů a dlouhých kostí horních končetin. Podle toho lze určit, že zemřelý byl pohřben hlavou k západu. Levá ruka byla natažena a pravá směřovala do klína, polohu nohou určit nelze. Spodní část těla, ramena a dolní část lebky byly odstraněny dvěma recentními výkopy. Lebeční kosti byly středně- až silnostěnné, se synostozovanými i částečně obliterovanými lebečními švy. Kosti postkraniálního skeletu byly gracilní až středně robustní stavby, s plně přirostlými epifýzami. Mezi variety řadíme otvor v trochleární jamce - foramen supratrochleare. Závěr: neurčitelný jedinec, maturus I+ (nad 40 let).

Kromě výše uvedených kostí byly při začištování hrobů H2 a H3 nalezeny ještě další kosti - zlomky kosti pánevní, kosti křížové, proximální hlavice femuru, zlomky kosti holenní, kosti lýtkové, pravé kosti patní a pravá kost hlezenní a prstové články ruky. Stavba kostí je středně robustní, epifýzy plně přirostlé. Kosti náleži dospělému, př́ípadně několika dospělým jedincům. Je zřejmé, že patří pohřbeným z hrobů $\mathrm{H} 2$ a $\mathrm{H} 3$, pro jejich fragmentárnost je však nelze konkrétně přiřadit. Patologické nálezy: na acetabulu drobné léze.

\section{Hrob 4 (obr. 4:4)}

Větší část hrobu s obdélnou hrobovou jámou zaoblenou za hlavou pohřbeného. Dochovaná délka $1,65 \mathrm{~m}$, šiřka až $0,65 \mathrm{~m}$. Hrobová jáma nebyla zahloubena do podloží, výplň byla zjištěna $\mathrm{v}$ síle $0,15 \mathrm{~m}$. Kostra se dochovala téměř celá, recentními výkopy byla odstraněna kolena a spodní část nohou. Zemřelý byl pohřben v natažené poloze hlavou k západu. Pravá ruka byla natažena podél těla, levá je ohnuta na břicho. Nohy byly nataženy. Lebka byla natočena obličejem k severu. Z kostry se zachovala fragmentární lebka a ve zlomcích kosti postkraniálního skeletu. Lebeční fragmenty byly středně silnostěnné, s otevřenými a srůstajícími lebečními švy. Mandibula je se středně vysokým tělem, zaobleným trigonum mentale a rovnými úhly. Chrup byl středně silně, na některých zubech silně obroušen. Kosti postkraniálního skeletu byly střední až robustní stavby, se středně výrazným reliéfem svalových úponů a plně přirostlými epifýzami. Pánevní pohlavně determinační znaky jsou mužské (metrické charakteristiky - DSP zařadily pánev s 99\% pravděpodobností mezi muže). Index platymerický spadal do kategorie platymerie (sin-76,9; dx-82,7). Patologické nálezy: dva zubní kazy, čtyři intravitální ztráty, hypoplazie skloviny. Schmorlovy uzly na hrudních obratlích, artrotické lemy okolo proximální hlavice levé kosti stehenní, zánětlivé změny v okolí fovea capitis femoris sin. Závěr: muž, adultus II - maturus I (35-45 let). Př́měs: žebro (Bos taurus f. domestica - určil R. Kyselý).

\section{Hrob 5 (obr. 4:5)}

Větší část hrobu s původně nejspíše obdélnou hrobovou jámou se zaoblenými rohy (za hlavou). Dochovaná délka činí $1,1 \mathrm{~m}$, maximální šířka $0,7 \mathrm{~m}$. Hrobová jáma byla zahloubena 0,05 až $0,15 \mathrm{~m}$ do podloží. $Z$ kostry se dochovaly fragmenty lebky, zlomky krčních obratlů, žeber, obou lopatkových pletenců, kostí pažních, kostí pánevních a proximální části obou kostí stehenních. Zemřelý byl pohřben na zádech hlavou k západu. Polohu rukou nelze určit, nohy byly nataženy. Lebka byla otočena obličejem k jihu. Hrudník a dolní část nohou byly odstraněny dvěma recentními výkopy. Pod levou paží zjištěny drobné stopy dřeva. Lebeční fragmenty byly gracilní stavby, slabě svalově modelované, s lebečními švy v různém stupni srůstu. Nadoboční oblouky 
jsou ploché, vnější týlní hrbol nebyl vytvořen. Mandibula je s nízkým tělem a zaoblenou bradou. Dochovaný chrup je velmi silně abradován, na některých zubech až ke krčku. Patologické nálezy: minimálně sedm intravitálních ztrát, spondylóza II. stupně na třetím krčním obratli, spondylartróza na dens axis. Závěr: spíše žena, maturus II - senilis (nad 50 let).

\section{Hrob 6 (obr. 4:6; 6)}

Větší část hrobu s obdélnou hrobovou jámou se zaoblenou kratší stranou za hlavou. Dochovaná délka je 2,02 m, maximální šířka $0,55 \mathrm{~m}$. Hrobová jáma byla zahloubena $0,1 \mathrm{~m}$ do podloží. Pod lebkou byly zjištěny stopy dřeva. Z kostry se dochovaly fragmentární lebka, ve zlomcích obratle, žebra, dlouhé kosti obou horních končetin, několik zlomků obou kostí pánevních a proximální hlavice kosti stehenní. Pohřbený byl uložen na zádech hlavou k západu. Ruce byly nataženy podél těla, polohu nohou nelze určit, protože byly odstraněny dvěma recentními výkopy. Lebeční fragmenty byly středně silnostěnné, se synostozovanými lebečními švy. Mandibula je s vysokým tělem, rovnými až mírně evertovanými gonii a oblým trigonum mentale. Chrup byl středně silně obroušen. Kosti postkraniálního skeletu se vyznačovaly robustní stavbou a výrazným reliéfem svalových úponů, epifýzy byly plně přirostlé. Na pánvi byla zjištěna úzká a hluboká incisura ischiadica major. Patologické nálezy: hypoplazie skloviny na dolních špičácích, slabé artrotické změny po obvodu proximální hlavice femuru, artrotické změny na proximální radioulnární kloubní ploše sin, spondylóza III.-IV. stupně na bederním obratli, slabá spondylartróza na hrudních obratlích. Pravděpodobně nespecifický zánět byl identifikován v proximální kloubní ploše levé kosti pažní (oblast je však poškozena). Drobný okrsek periostitidy na temporální kosti. Závěr: muž, maturus I (35-50 let).

Malý vzorek nedovoluje zevšeobecnění poznatků o hrobovém ritu, který nevybočuje z rámce, jenž je doložen na jiných mladohradištních pohřebištích. Zkoumané hroby spojuje minimální nebo žádné zahloubení do podloží, které indikuje spíše mělkou původní hrobovou jámu. Doložen je různý tvar hrobové jámy, méně obvyklý je trapezoidní tvar (H1). Při úpravě hrobové jámy nebyl použit kámen, zjištěné stopy dřev ve dvou hrobech nelze hodnotit (H5, H6). S uložením do hrobu zřejmě souvisí svázání nebo těsné ovinutí zemřelého v hrobě H1, které se víceméně vylučuje s použitím rakve, ale nelze ho prř́močaře charakterizovat jako opatření proti revenanci. Orientace koster je obvyklá. Zjištujeme vyšší zastoupení jedné ohnuté ruky (celkem třikrát), ale může to být způsobeno malou reprezentativností vzorku. Stejně je tomu s natočením lebky obličejem k jihu nebo severu (také třikrát).

\section{Datování}

Ve snaze ověřit předpokládané mladohradištní datování hrobů byl odebrán vzorek kosti z hrobu H1 a zaslán na radiouhlíkové datování. Vzorek označený 17_253 byl mechanicky očištěn od zbytků zeminy. Měření v laboratoři HEKAL ATOMKI HAS v Debrecenu s mezinárodním kódem DebA bylo realizováno na kompaktním tandemovém urychlovači se spektrometrickou trasou MICADAS. Pro určení stáŕí vzorků byl použit kalibrační program OxCal, v souladu s dostupnými údaji o vzorku byla použita kalibrační křivka IntCal13. Po přiřazení nejistot daných radiouhlíkovou kalibrační křivkou bylo konvenční radiouhlíkové stáří a jeho kombinovaná nejistota přepočteno na interval (intervaly) kalibrovaného stáří (pro interval nejistoty 2sigma

\begin{tabular}{|c|c|c|c|c|}
\hline Lab. č. vzorku & Popis datovaného vzorku & $\begin{array}{c}\text { Konvenční radiouhlíkové } \\
\text { stáří (léta BP) }\end{array}$ & $\begin{array}{c}\text { Kalibrované stáŕí, hlavní } \\
\text { intervaly (léta AD) }\end{array}$ & P (\%) \\
\hline 17_253 & $\begin{array}{c}\text { Chrudim - Dašická ul., 2015, } \\
\text { hrob H1, sáček 134 (zlomky } \\
\text { žeber) }\end{array}$ & $957 \pm 18$ & $\mathbf{1 0 2 2 - 1 1 5 4}$ & $\mathbf{9 5}$ \\
\hline
\end{tabular}

Tab. 1. Chrudim - Dašická ulice. Radiouhlíkové datování hrobu H1.

Tab. 1. Chrudim - Dašická-Str. Radiokarbondatierung von Grab H1. 


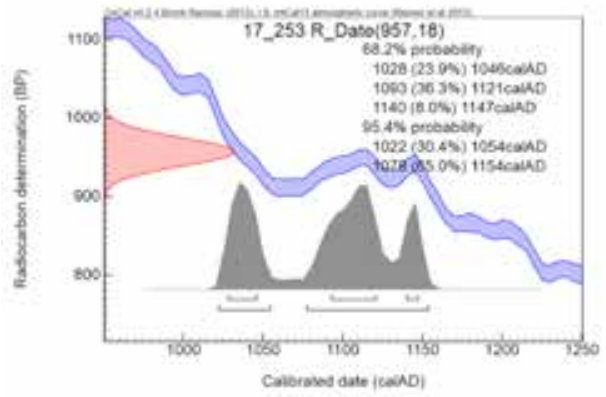

Obr. 7. Chrudim - Dašická ulice, hrob H1 - radiouhlíkové datum.

Abb. 7. Chrudim - Dašická-Str., Grab H1 - Radiokarbondatum.

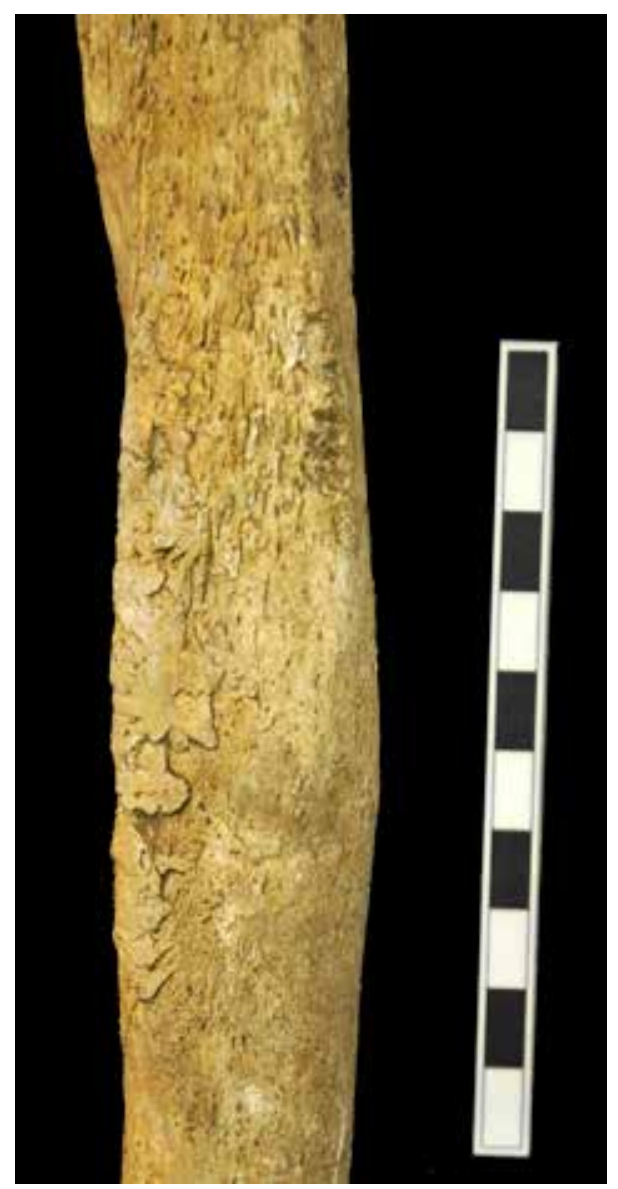

Obr. 8. Chrudim - Dašická ulice, hrob H1. Periostitida na pravé kosti holenní, muž, maturus II - senilis. Foto E. Zazvonilová.

Abb. 8. Chrudim - Dašická-Str., Grab H1. Periostitis am rechten Schienbeinknochen, Mann, maturus II - senilis. Foto E. Zazvonilová. stanovení aktivity ${ }^{14} \mathrm{C}$, který odpovídá pravděpodobnosti přibližně $95 \%$ - Světlík 2017).

Výsledná křivka rozděluje získané datování na dva intervaly (obr. 7), a to 1022-1054 a 1078-1154 n.l. Vzhledem k absenci milodarů mohou oba vymezovat dobu existence pohřebiště.

\section{Charakteristika pohřbené populace}

Ze šesti hrobů byly vyzvednuty pozůstatky šesti dospělých jedinců - jedné ženy?, tř́i mužů a dvou jedincủ neurčitelných. Všichni pohřbení byli starší 30 let, dva nejspíše dosáhli až stařeckého věku (muž z hrobu H1 a žena z hrobu H5). Spočívali v natažené poloze na zádech, s horními končetinami podél těla, případně s jednou rukou směřující do klína (H1, H3, H4). Polohu dolních končetin bylo možné určit pouze u hrobů H1, H4 a H5. Hroby $\mathrm{H} 2$ a $\mathrm{H} 3$ byly narušeny recentními výkopy a dolní končetiny nebyly zachovány. Mužské kostry byly středně robustně až robustně stavěny, ženská kostra se vyznačovala střední až gracilnější tělesnou stavbou. Vývin svalového reliéfu odpovídal tělesné stavbě. Pokud to zachovalost kostry dovolovala, zjistili jsme u všech jedinců poškození chrupu - zubní kazy, intravitální ztráty, hypoplazii skloviny (H1, H4, H5, H6). Časté byly také degenerativně produktivní změny na páteři - spondylóza, spondylartróza (H1, H2, H5, H6) a artrotické změny na kloubních plochách $(\mathrm{H} 1, \mathrm{H} 4$, H6). Kostra muže z hrobu H1 nesla stopy zvýšené tělesné námahy nejspíše spojené s intenzivní chůzí po nerovném povrchu a se zatížením pletenců horních končetin, což může být dokladem provádění například zemědělských prací (orby) nebo nošení břemen zavěšených na zádech. Periostitida na kostech dolních končetin (obr. 8) může být následek traumatu souvisejícího s vykonávanou činností. Metrické charakteristiky na jednotlivých kostech ani tělesnou výšku nebylo možné, až na dvě výjimky ve formě indexu platymerického, zjistit.

I přesto, že se jedná pouze o velmi malý vzorek raně středověké populace, navíc v nedobrém stavu zachovalosti, předpokládáme na základě zjištěných známek na kostrových pozůstatcích, že pohřbení jedinci byli příslušníky nejspíše zemědělské populace, jejiž životní podmínky nebyly prríliš kvalitní. 


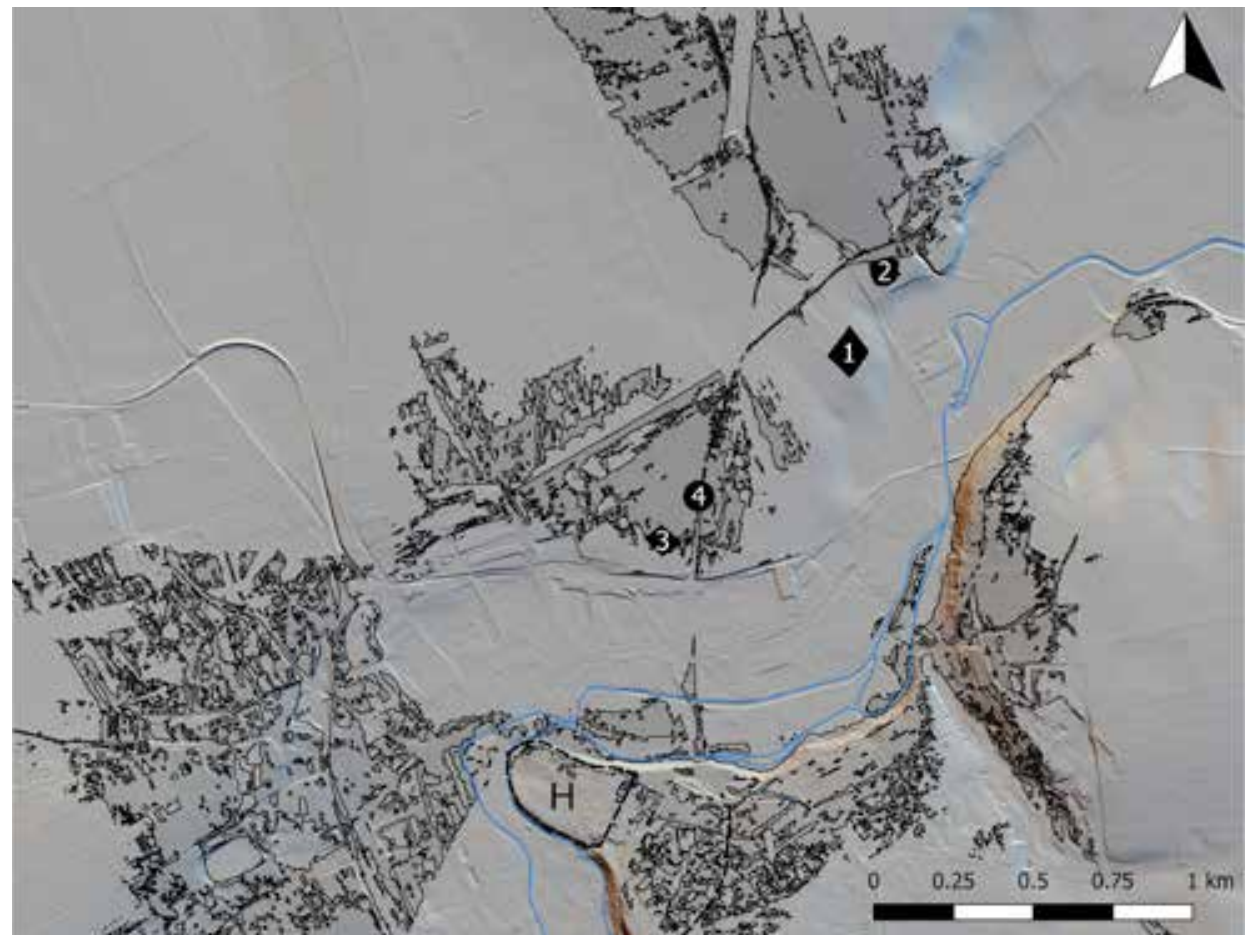

Obr. 9. Vazba pohřebiště na okolní sídlištní sít. H - poloha chrudimského hradiště, šrafovaně přímá viditelnost z pohřebiště v Chrudimi, Dašické ulici; 1 - Chrudim, nal. 19; 2 - Chrudim, nal. 20; 3 - Chrudim, nal. 45; 4 - Chrudim, Dašická ul. Podkladová mapa DMR5G (zdroj ČÚZK) vizualizovaná metodou Hillshading for multiple direction. Vytvořeno v programu RVT a QGIS.

Abb. 9. Anbindung des Gräberfeldes an das umliegende Siedlungsnetz. H - Lage des Chrudimer Burgwalles, schraffiert direkte Sichtbarkeit vom Gräberfeld in Chrudim aus, Dašická-Str.; 1 - Chrudim, Fundstelle 19; 2 - Chrudim, Fundstelle 20; 3 - Chrudim, Fundstelle 45; 4 - Chrudim, Dašická-Str. Kartenvorlage DMR5G (Quelle Amt für Landesvermessung und Kataster) visualisiert durch Hillshading for multiple direction. Erstellt mit der Software RVT und QGIS.

\section{Možné vazby na raně středověkou sídlištní strukturu}

Důležitou otázkou, kterou je třeba si pokládat, je vazba objeveného pohřebiště na soudobou sídlištní sít'. V základních rysech byl podán obraz jejího rozsahu v již citované práci J. Frolíka a J. Sigla věnované vývoji a transformaci raně středověkého osídlení na Chrudimsku (FrolíkSigl 1995). V našem př́ipadě sehrává hlavní roli analýza terénní konfigurace. Pohřebiště se nalézá na výrazné terase nad řekou Chrudimkou, která tvořila určitou komunikační bariéru mezi tímto pohřebištěm a aglomerací chrudimského hradiště. Na této terase v severním sousedství hradiště se ve vzdálenosti do $1 \mathrm{~km}$ od pohřebiště nalézají celkem tř̌i sídlištní polohy. Nejbližší je naleziště 45 (Frolík-Sigl 1995, 15) s relativně málo četnými nálezy keramiky 12.-13. století a jednou shodně datovanou železnou šipkou (Musil 2007), další dvě naleziště jsou položená ve vzdálenosti 0,7 a 1 km severovýchodně od pohřebiště (naleziště 19 a 20 - Frolík-Sigl 1995, 15), leží již na rozhraní katastru Chrudimi a Vestce. Jak se jeví na základě našich dosavadních poznatků, naleziště 19 v poloze Májov má své počátky již ve středohradištním období. Do mladohradištního období pak spadá nedaleké naleziště 20. Intenzivní osídlení 12.-13. století v těsném sousedství naleziště 20 doložil i archeologický výzkum při stavbě obchvatu Chrudimi v letech 2011-2013 (Musil 2014). Zajímavé výsledky přinesla i analýza viditelnosti z pohřebiště (obr. 9). $\mathrm{Z}$ pohřebiště je při výšce $2 \mathrm{~m}$ nad terénem možno dohlédnout na naleziště 45 a částečně i na 
naleziště 20, přičemž ani areál hradiště, ani sídliště v poloze Májov (naleziště 19) nebylo možno z pohřebiště zahlédnout.

$\mathrm{Z}$ těchto důvodů (několik terénních stupňů, nedobrá viditelnost) soudíme, že objevené pohřebiště v Dašické ulici souvisí spíše $\mathrm{s}$ venkovským osídlením, konkrétně s primárními jádry osídlení, ze kterých později vznikla osada Vestec.

\section{Středohradištní a mladohradištní pohřebiště v Chrudimi}

Na katastru Chrudimi se setkáváme s větším počtem pohřebišt' $\mathrm{z}$ období před vznikem vrcholně středověkého města (obr. 1). Ve všech př́ípadech se jedná o nevelká torza, která dokládají jejich existenci, ale neposkytují dostatečné informace o pohřebním ritu, výbavě hrobů nebo jejich úpravě. Totéž platí pro možnost blíže poznat na základě antropologie soudobou populaci.

Dvě pohřebiště můžeme charakterizovat jako kostelní. Z okolí kostela Nanebevzetí Panny Marie na Resslově náměstí v centru města známe dva kostrové hroby (obr. 1:1,2), oba porušené mladšími sídlištními situacemi (Frolík-Sigl 1994; Kytlicová 1956). Tyto hroby považujeme za okrajovou část pohřebiště u (románského) předchůdce gotického kostela (Frolík-Sigl 1998, 26). $Z$ bezprostředního okolí kostela je dále známo několik záušnic (doloženy čtyři, dochovány dvě), objevených již v 19. století (Frolík 1981; Lüssner 1857; 1857a). Pohřebiště je datováno do 11.-12. století. Další kostelní pohřebiště je známo u staršího předchůdce gotického kostela sv. Kříže na jihovýchodním okraji chrudimské raně středověké sídelní aglomerace (obr. 1:3). V 19. století zde byly na hřbitově získány záušnice (celkem osm, dochováno šest) a tři denáry (Vladislav II. a Soběslav II. - Lüssner 1868; Frolík 1981). S tímto pohřebištěm pravděpodobně souvisí šest hrobů objevených západně od hřbitova na parcele č. 1460/1 (Vokolek 1955), které však mohou být i o něco mladší (nebyly získány datovatelné nálezy).

V ploše přemyslovského správního hradiště byl na dvoře čp. 27/I ve Filištínské ulici narušen kostrový hrob (obr. 1:4), který byl podle keramiky v zásypu datován do mladohradištního období (Frolík-Sigl 1995, 64). Další kosterní ostatky společně s jedním keramickým zlomkem byly na dvoře za čp. 35/I získány v roce 2007 (obr. 1:5 - Musil 2008-2009, 36). Kostrový hrob (novorozenec) byl objeven v mladohradištním souvrství při výzkumu v Hradební ulici v roce 2006 (Frolík-Musil 2006). Vzhledem k ojedinělosti nálezu na rozsáhlé zkoumané ploše se nejedná o součást neznámého pohřebiště, ale o pohřeb v rámci sídlištní situace (obr. 1:6). Zatímco předchozí hroby byly vykopány na akropoli hradiště, pohřebiště objevené při stavbě budovy gymnázia na Školním náměstí je situováno na předhradí (obr. 1:7). V roce 1863 zde bylo nalezeno několik hrobů pod velkými kameny, tři lebky a kosti a u jedné z lebek bronzová pozlacená záušnice (Lüssner 1864; Frolík-Sigl 1995, 64). Pohřebiště je datováno do 12.-13. století.

Další pohřebiště nacházíme v rámci sídelní aglomerace obklopující chrudimské hradiště. V roce 1893 byl nalezen hrob se dvěma záušnicemi a denárem Vratislava II. (Šolta 1898; Frolík-Sigl 1995, 64) v Husově ulici nedaleko od kostela sv. Kateřiny, tj. jihovýchodně od hradiště, ale nikoli u okraje sídelní aglomerace (obr. 1:8). Ne zcela jednoznačný je soubor nálezů z areálu továrny Wiesner/Transporta (Čáslavská ulice), tvořený dvěma mladohradištními nádobami (obr. 1:9). Souviset s nimi může nález dvou záušnic z Masarykova náměstí v sousedství bývalé Wiesnerovy vily (obr. 1:10), tedy v sousedství zmíněného továrního areálu (Frolík-Sigl 1995, 64). Žádný z uvedených nálezů nedoprovází kosterní ostatky. Naleziště se nachází západně od hradiště. V roce 1980 byl na staveništi nového sídliště při Topolské ulici narušen při skrývce kostrový hrob (objekt 15/80). Kosti byly neodborně vyzdviženy, ale na místě bylo možno ověřit jejich původní polohu (obr. 1:11). Sběrem na ploše ve směru pohybu zemních strojů byly sesbírány střepy nádoby (obr. 10:1) a torzo železného nože. Podle toho byl hrob zařazen do mladohradištního období (Frolík 1982; Frolík-Sigl 1995, 64). Během dalšího výzkumu bylo prozkoumáno ještě dalších šest hrobů, které byly datovány do neolitu. Datování však není považováno za průkazné (Zápotocká 2004, 4-5). ${ }^{2}$ Hrob (pohřebiště) je situován na východním okraji chrudimské

2 Při dohledávání nálezů nebyl inventár̆ uvedených hrobů s výjimkou kostrového materiálu hrobů označených H4 až H6 nalezen (Zápotocká 2004, 5). Není tedy zřejmé, podle čeho jsou další hroby zařazeny do neolitu (Nováková 1981). 
aglomerace. Poslední pohřebiště bylo nedávno identifikováno díky studiu dobových tiskovin. V areálu továrny Chrástka \& Jelínek (dnešní čp. 428 v Jiráskově ulici) byly v roce 1913 objeveny kostrové hroby, datované $\mathrm{v}$ době nálezu do 11.-12. století. ${ }^{3}$ Jiné informace a ani nálezy se nedochovaly (obr. 1:12).

\section{Vesnická středohradištní a mladohradištní pohřebiště na Chrudimsku a Pardubicku}

Problematice středohradištních a mladohradištních pohřebišt' ve sledovaném regionu byla v minulosti věnována pozornost při studiu vývoje osídlení v tomto období na základě projektu povrchového průzkumu (Frolík-Sigl 1995). Při té př́ležitosti byly shromážděny také všechny informace o nálezech hrobů/pohřebišt' a předmětů hrobového charakteru. ${ }^{4}$ Celkem bylo evidováno 48 lokalit $\mathrm{s}$ těmito nálezy. Mezi nimi však jen menší část náleží $\mathrm{k}$ vesnickým pohřebištím (celkem 15 nalezišt' - Bezděkov, okres Pardubice, dále jen PA; Brčekoly, okres Chrudim, dále jen CR; Čankovice, CR; Dašice, PA; Dražkovice, PA; Chrudim, Husova ul.; Chrudim, Topolská ul.; Chrudim, Jiráskova ul.; Jezbořice - Klešice, PA; Moravany, PA; Rosice - dvě polohy, CR; Slatiňany-dvě polohy, CR; Štěpánov, CR - Frolík-Sigl 1995, 63-66). Do tohoto výčtu nejsou zahrnuty lokality s ojedinělými nálezy hrobového charakteru (např. Luže, CR - dvě záušnice bez nálezových okolností; Úhřetice, CR - záušnice bez dalších okolností), které by celkový počet mírně navýšily. Těchto 15 nalezišt' (obr. 11) představuje pouze 38 jednotlivě popsaných hrobů (a neznámý počet hrobů dalších, uvedených při popisu nálezových okolností pouze sumárně). Již v roce 1995 bylo konstatováno, že počet známých pohřebišt', natož jednotlivých hrobů je velmi nízký a představuje méně než čtvrtinu (nebo až méně než desetinu, podle použité metody výpočtu) předpokládaných pohřebišt' pro období 9. až 13. století (Frolík-Sigl 1995, 62-63). Př́irůstek nových lokalit byl sporadický a omezoval se na jednotlivé hroby nebo jejich malé skupiny (Bezděkov - 4 hroby; Čankovice - 1 hrob; Chrudim, Topolská ul. - 1 (?) hrob; Rosice - 2 hroby).

Intenzivní archeologické výzkumy prováděné na Chrudimsku od 80. let minulého století však počet vesnických pohřebišt' překvapivě nenavýšily. Konkrétně přibyla pouze referovaná lokalita Chrudim - Dašická ulice. Minimální přírůstek nalezišt' překvapuje také proto, že na Pardubicku i Chrudimsku byl proveden větší počet i velmi rozsáhlých terénních odkryvů (např. dálniční př̀ivaděč Chrudim - Pardubice, obchvat Chrudimi apod.). Náhradou nemohou být raně

\begin{tabular}{|c|c|c|c|}
\hline Období & Počet pohřebišt' & Počet popsaných hrobů & Další nálezy hrobového charakteru \\
\hline do roku 1900 & 5 & $28+\mathrm{x}$ & 5 \\
\hline $1901-1950$ & 6 & $2+\mathrm{x}$ & 10 \\
\hline $1951-2000$ & 4 & 8 & 4 \\
\hline od 2001 & 1 & 6 & - \\
\hline
\end{tabular}

Tab. 2. Raně stř̌edověká vesnická pohřebiště na Chrudimsku a Pardubicku. Počet pohřebišt’ a jednotlivých hrobů od roku $1851 ;$, "x“ znamená další, početně však neuvedené hroby.

Tab. 2. Frühmittelalterliche Dorfgräberfelder in der Region Chrudim und Pardubice. Anzahl der Gräberfelder und Einzelgräber seit dem Jahr 1851; ,x“ bedeutet weitere, zahlenmäßig jedoch nicht angegebene Gräber.

\footnotetext{
3 Chrudimský kraj, č. 1, 31. 5. 1913, strana 2: „Nález kostí. Při odkopáváni hlíny na nádvoři strojnické továrny fy Chrástka \& Jelinek odkryty byly v úterý ve hloubi $60 \mathrm{~cm}$, lidské kostry, snad ruských vojínů, kteři r. 1813 ve špitále, kde se nyni nalézá závod pánů Němce a Pokorného, zemřeli. Kosti byly p. adjunktem musea Štěrbou ofotografovány a na hřbitově pochovány. Přitomnému p. ob. st. insp. Moučkovi bylo nápadné okrouhlé misto asi $1 \mathrm{~m}$ v průměru, jevici červenou zemi jako po spálené hlíné; poněvadž tam nalezena část popelnice, zdá se, že tu jde o prahistorický hrob, a proto zastavil dalši kopáni až na dalši nařizeni.“ - Chrudimský kraj, č. 9, 25. 4. 1914, strana 3: „Pohřebiště z doby knižecí v Chrudimi. Prof. J. Matiegka v ,Pravěku' 1912 stanovil program prehistorické demografie, jež nám má podati konkrétni poznatky o stavu a složeni společnosti lidské. (...) A to pro pozdější dobu knižecí v Čechách mủže, aspoň částečně poskytnouti materiál i naše město. Na svahu, jenž jest přerván severozápadním nádražim u továrny p. Chrástky, odkryto loni na podzim pohřebiště z první doby křest’anské, kdež mrtví pochováni podle tehdejšiho způsobu hlavou k západu tak, aby hleděli $k$ východu slunce. Střepy, jenž při hrobech těch nalezeny, jsou asi ze 12. stoleti, nejvýse ještě ze stol. 11. Letos při odkopávání hliny se svahu tohoto nalezeny kostry dalši. Bude tudiž předním úkolem v těchto mistech, aby každý kostrový nález byl rádnè ohledán, do situačního plánu zakreslen a aby byly zachovány kostrové zbytky, na jejichž základě by se mohlo určiti pohlaví a stář́ osob zde pochovaných."

4 Za předměty hrobového charakteru pokládáme převážně ojedinělé nálezy celých středohradištních a mladohradištních nádob, šperků či zbraní. Tyto nálezy mají obvykle velmi kusé nálezové okolnosti.
} 

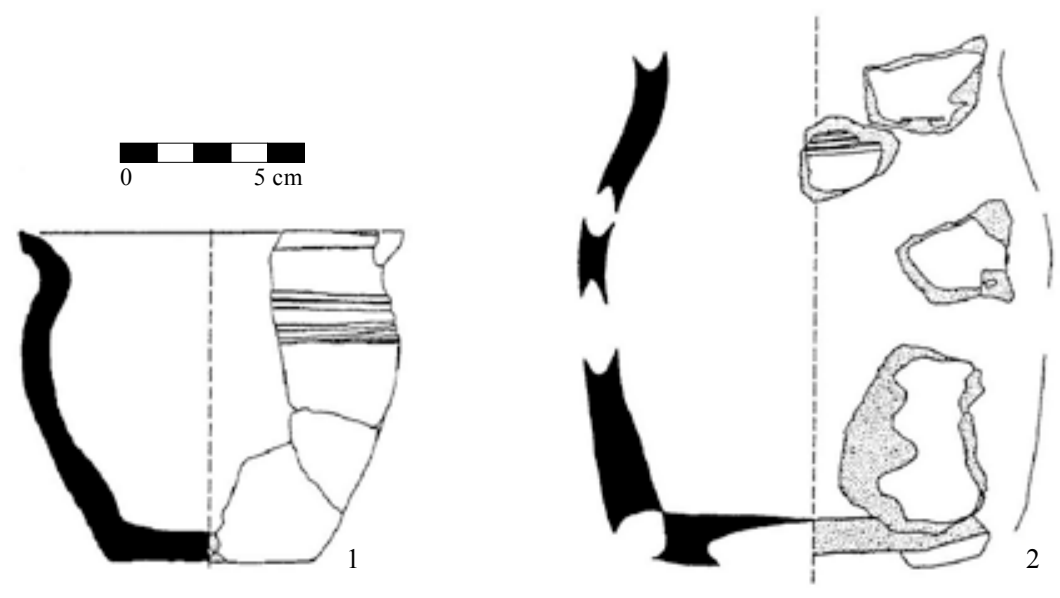

Obr. 10. 1 - Chrudim, Topolská ulice, nálezy z hrobu 1 (objekt 15/80); 2 - Čankovice, hrob 1. Kresba J. Frolík. Abb. 10. 1 - Chrudim, Topolská-Str., Grabfunde 1 (Objekt 15/80); 2 - Čankovice, Grab 1. Zeichnung J. Frolík.

středověké hroby odkryté u zkoumaných církevních staveb jako součást etážových pohřebišt' (Hrochův Týnec, CR; Chrast - Chrašice, CR; Chrudim - hrad; Jezbořice, PA; Lažany, CR; Podlažice, CR; Přelouč, PA - Frolík 2007; 2017). Pohřebiště byla objevována a povědomost o nich je uchovávána již od roku 1851 (Dašice, PA - Frolík-Sigl 1995, 63), ale počet nově objevovaných nalezišt' i zkoumaných hrobů se neustále snižuje.

Za 167 let registrace nálezů bylo zjištěno pouze 16 vesnických (řadových) raně středověkých pohřebišt', či přesněji jejich nevelkých torz. Počet jednotlivě popsaných hrobů je pouze 44 (a další neupřesněné množství). Největší skupiny představují shodou okolností dvě nejstarší evidovaná pohřebiště (Dašice - 11 hrobů; Dražkovice - 16 hrobů), u nichž schází bližší informace o podobě jednotlivých hrobů či o jejich vzájemném uspořádání (Diviš 1884; Nechvíle 1976; Smolík 1884). Naleziště evidovaná po roce 1950 představují torza narušených pohřebišt' (Bezděkov - 4 hroby, Kašpárek-Zavoral-Cebová 2014; Rosice - 2 hroby, Rataj 1952; 1954) nebo jen jednotlivé hroby (Čankovice -1 hrob; Chrudim, Topolská ul. - 1 hrob). Jednotlivá naleziště byla objevena či zkoumána s velkými časovými odstupy (Rosice 1952; Čankovice 1968; Bezděkov 1971; Chrudim, Topolská ul., 1980; Chrudim, Dašická ul., 2015). Z celkového počtu všech hrobů jich pouze 13 bylo odborně dokumentováno (Bezděkov - 4 hroby; Čankovice -1 hrob; Chrudim, Dašická ul. -6 hrobů; Rosice -2 hroby). Popsanou situaci považujeme za varovnou, protože dosud neznáme z Chrudimska či Pardubicka žádné vesnické raně středověké pohřebiště prozkoumané (v ideálním případě) v úplnosti nebo alespoň z takové části, aby byly získané poznatky statisticky hodnotitelné (pohřebiště o nejméně několika desítkách hrobů).

\begin{tabular}{|c|c|c|}
\hline Období & Počet pohřebišt'/lokalit & Poznámka \\
\hline $1963-1972$ & 62 & - \\
\hline $1973-1982$ & 48 & jedno ve východních Čechách \\
\hline $1983-1989$ & 20 & žádné ve východních Čechách \\
\hline $1990-1999$ & 19 & žádné ve východních Čechách \\
\hline $2000-2009$ & 17 & \\
\hline
\end{tabular}

Tab. 3. Počet zkoumaných raně středověkých pohřebišt' v Čechách v období 1963-2009.

Tab. 3. Anzahl der im Zeitraum zwischen 1963-2009 untersuchten frühmittelalterlichen Gräberfelder in Böhmen. 


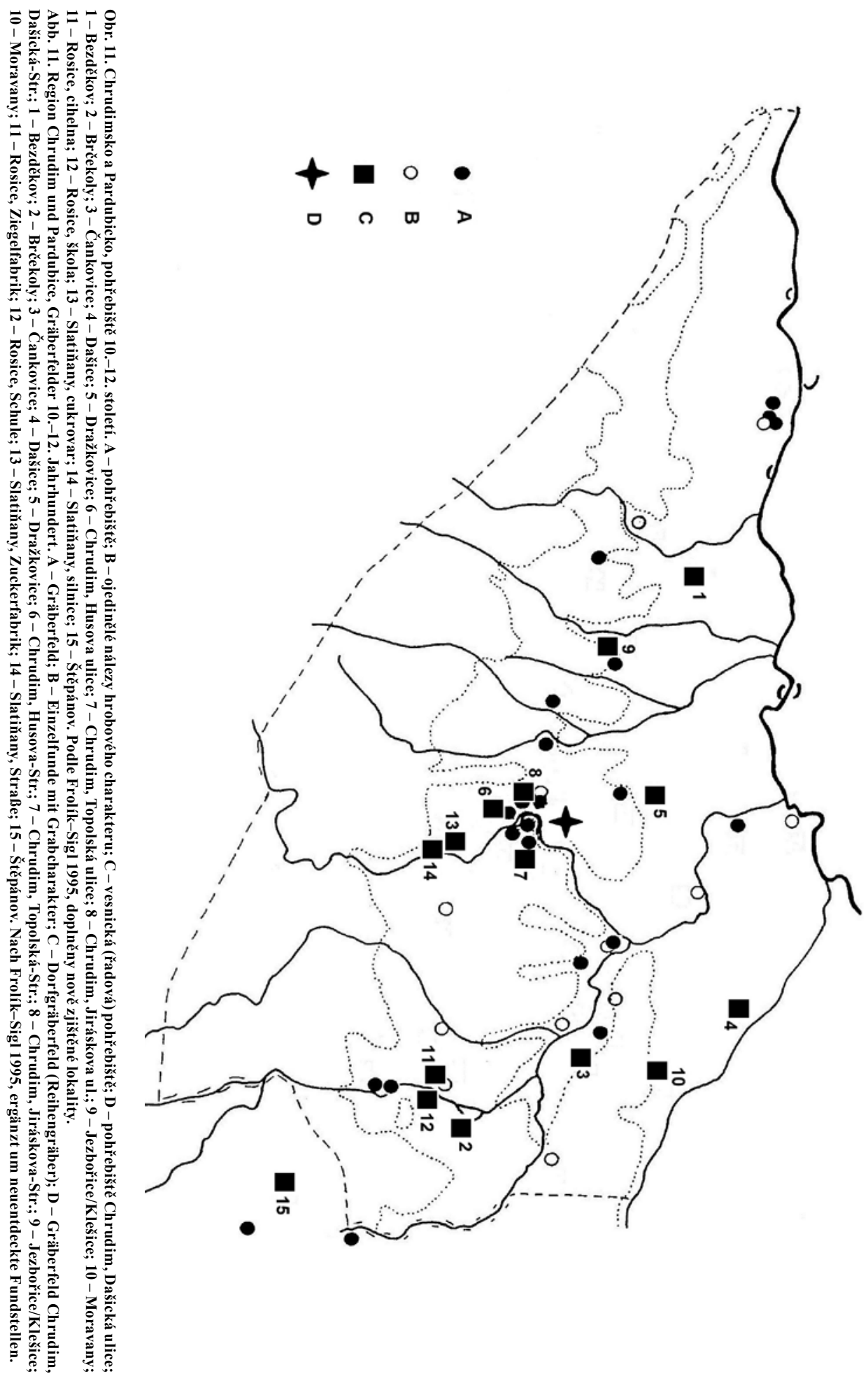


Porovnáme-li situaci zjištěnou na Chrudimsku a Pardubicku s celými Čechami, zjišt’ujeme stejně neblahou situaci. Na nízký přírůstek počtu raně středověkých vesnických pohřebišt' upozornil již před 30 lety J. Klápště (1989). Jeho pozorování dnes můžeme prodloužit do roku 2009. K výčtu dodáváme, že pouze pět nalezišt' se podle počtu hrobů nachází v rozmezí „10 až 50 “ a v kategorii „více než 50 hrobư“ je po roce 1990 pouze jediné (Zeleneč, okr. Praha-východ).

Statistiku můžeme protáhnout také do minulosti, ale pouze pro střední Čechy. Soupis pohřebišt' i nálezů hrobového charakteru eviduje před rokem 1916 celkem 183 lokalit, v období 1914-1944 se př́růstek snížil na 136 lokalit a v období do roku 1970 dokonce na 60 lokalit (Sláma 1977; Klápště 1989, 81). Jedná se tedy o dlouhodobou tendenci, pro kterou nestačí vysvětlení, že je to důsledek postupného vyčerpávání celkového počtu pohřebišt'. Na Chrudimsku a Pardubicku se díky intenzivnímu povrchovému průzkumu podařilo doložit hustou sít' sídlišt' od středohradištního období a jejich rozčlenění do tzv. sídlištních komplexů (Frolík-Sigl 1995). Pro část komplexů neznáme žádné pohřebiště. Stejně tak neznáme žádné kostrové pohřebiště, které bychom mohli datovat do 9. století, snad s výjimkou hrobu z Čankovic (obr. 10:2). Stejnou situaci konstatoval J. Klápště $(1989,82)$ pro povodí Lomského potoka na Bílinsku. Spolu s pozorováními z roku 1989 (Klápště 1989, 81-82) můžeme zopakovat, že značný význam má změna charakteru zemních prací (dnes převážně pouze s pomocí mechanizace) - kromě velkokapacitních lžic zemních strojů má nově vliv jistě i použíání posuvných bednění a jiných způsobů, které znepřístupňují dlouhé úseky stěn výkopů. Totéž platí pro dosti důsledné odvážení zeminy z prostoru výkopových prací. Na straně druhé však nepřibyl (překvapivě) významnější počet pohřebišt jako důsledek velkoplošných záchranných výzkumů vyvolaných výstavbou a velkými infrastrukturními projekty. Převahu mají nadále objevy v rámci nevelkých výkopů nebo při liniových stavbách obvykle pouze s jednotlivými hroby. Jen vzácně vede objev ojedinělého hrobu k plošně rozsáhlejšímu výzkumu (Zeleneč).

O prríčinách tohoto stavu můžeme jedině spekulovat. Pokud bychom zobecnili nálezovou situaci dvou největších pohřebišt' Chrudimska a Pardubicka (Chrudim, Dašická ul. - 6 hrobů; Bezděkov -4 hroby), může být př́ičinou silné narušení hrobů orbou, protože ty se na obou pohřebištích nacházely na bázi ornice nebo v podorničí a byly jen mělce zahloubeny do podloží. V této souvislosti se nabízí otázka, kolik hrobů, respektive pohřebišt' mohlo zaniknout na staveništích, kde nebyl u skrývky př́tomen archeolog.

\section{Závěr}

Řešení nastíněné situace, tedy zabránění ztrátě (či přesněji nezískávání) informací o raně středověkých pohřebištích, se mnoho nenabízí. Jednou možností je důsledná př́ítomnost archeologa při skrývkách všech větších ploch a v ideálním př́ípadě skrývka způsobem řízeným archeologem. U hrobů nalézaných v liniových výkopech by bylo vhodné usilovat o možnost většího odkryvu. Ukazuje se, že na takto zjištěná naleziště se archeolog obvykle nevrací a jeden či několik málo torzovitě dokumentovaných pohřbů je na dlouhou dobu (často spíše navždy) jediným svědectvím o jeho existenci. U kostrových pohřebišt' je zatím problematická snaha o jejich nalezení nedestruktivními metodami zvláště tam, kde neznáme ani ojedinělé hroby, které by existenci pohřebiště naznačovaly.

Objev pohřebiště v Dašické ulici v Chrudimi považujeme za důležitý přínos k poznání chrudimské sídelní aglomerace v raném středověku. Z hlediska obecných archeologických problémů, jakým je vývoj nálezové základny, však vyvolává více otázek než odpovědí.

Článek vznikl jako součást projektu 14-36938G „Středověká populace v centru a na venkově. Archeologie, bioarcheologie a genetika na pohřebištích Pražského hradu, středních a východních Čech“ podporovaného Grantovou agenturou ČR. 


\section{Literatura}

DIVIŠ, V., 1884: Řadové hroby u Dražkovic, PA XII, 474-475.

FROLÍK, J., 1981: Archeologické nálezy Chrudimsko (Chrudim). Chrudim.

- 1982: Chrudim, Výzkumy v Čechách 1978, č. 9, 41.

- 2007: Záchranné výzkumy u středověkých kostelů na Chrudimsku a Pardubicku - Rettungsgrabungen bei einigen mittelalterlichen Kirchen in der Umgebung von Chrudim und Pardubice, Zprávy České archeologické společnosti - Supplément 68, Archeologické výzkumy v Čechách 2006. Sborník referátů $\mathrm{z}$ informačního kolokvia, 48-49.

- 2017: Pohřbívání ve vrcholném středověku a v novověku na Chrudimsku, Pardubicku a Kolínsku - Bestattungen im Hochmittelalter und in der Neuzeit in den Regionen Chrudim, Pardubice und Kolín, AH 42, $187-205$.

FROLÍK, J.-MUSIL, J., 2006: Záchranné archeologické výzkumy v Chrudimi v roce 2006 - Archäologische Rettungsgrabungen in Chrudim im J. 2006, Zprávy České archeologické společnosti - Supplément 68, $46-48$.

FROLÍK, J.-SIGL, J., 1994: New facts on the Settlement on the Central Hilltop of the Town of Chrudim. Rescue Survey of 1982-1984, PA LXXXV, 111-131.

- 1995: Chrudimsko v raném středověku. Vývoj osídlení a jeho proměny - Chrudim Region (East Bohemia) in the Early Middle Ages. Development of the Settlement and Related Structural Changes - Das Chrudimer Land im Frühmittelalter. Die Entwicklung der Besiedlung und seine strukturellen Probleme. Hradec Králové.

- 1998: Chrudim v pravěku a středověku. Obrazy každodenního života - Chrudim in Prehistory and the Middle Ages. Pictures of everyday Life - Chrudim in der Urgeschichte und in Mitelalter. Bilder aus dem Alltagsleben. Chrudim.

HARRIS, E. C., 1989: Principles of archaeological stratigraphy. 2nd edition. London - San Diego - New York - Boston - Sydney - Tokyo - Toronto.

KAŠPÁREK, F.-ZAVORAL, T.-CEBOVÁ, K., 2014: Raně středověké hroby z Bezděkova (okr. Pardubice) - Frühmittelalterliche Gräber auf dem Katastralgebiet von Bezděkov (Bez. Pardubice), AVČ Supplementum 1, 130-145.

KLÁPŠTĚ, J., 1989: Poznámky k některým tendencím v současném vývoji archeologické pramenné základny - Bemerkungenzu einigen Tendenzenn der Entwicklung der archäologischen Quellenbasis, AR XLI, 75-84.

KYTLICOVÁ, O., 1956: Slovanské sídliště v Chrudimi - Slavjanskoje selišče v Chrudimi - Habitat slave à Chrudim, AR VIII, 72, 92-93.

LÜSSNER, M., 1857: Archaeologické zprávy z Čech, PA II, 91-92.

- 1857a: Archaeologické zprávy z Chrudimska, PA II, 231.

- 1864: Zpráva o některých starožitnostech nalezených v Chrudimi r. 1861 a 1863, PA VI, 115-116.

- 1868: Kostel sv. Kříže v Chrudimi, PA VII, 495-506.

MUSIL, J., 2007: Nález středověké šipky z Chrudimi, ZMHK 33, 220-222.

- 2008-2009: Přehled archeologických akcí a př́ŕrsstků do sbírek Regionálního muzea v Chrudimi za rok 2007, ZMHK 34, 33-49.

- 2014: Zpráva o záchranném archeologickém výzkumu při stavbě obchvatu Chrudimi, Chrudimský vlastivědný sborník 18, 227-253.

- 2015: Předběžná zpráva o záchranném archeologickém výzkumu provedeném na základě dohody č. 19/15 a 50/2015 na lokalitě Chrudim, Dašická ul., akce: Modernizace silnice III/34026 Chrudim, železniční přejezd - napojení na I/37. Nálezová zpráva IDAV 53173, ulož. v archivu archeologického pracoviště Regionálního muzea v Chrudimi.

- 2015a: Archeologický výzkum při rozšiřování silnice v Chrudimi, Dašické ulici v roce 2015, Chrudimské vlastivědné listy 22 , č. $6,15-18$.

NECHVÍLE, J., 1876: Pohřebiště pohanské u Dašic, PA X, 617-618.

NOVÁKOVÁ, J., 1981: Záchranný archeologický výzkum pardubického muzea, Zprávy Klubu přátel Pardubicka $16,152-153$.

RATAJ, J., 1952: Rosice, nálezová zpráva čj. 2472/52, ulož. v Archivu ARÚ AV ČR, Praha, v. v. i.

- 1964: Rosice, nálezová zpráva čj. 1089/64, ulož. v Archivu ARÚ AV ČR, Praha, v. v. i.

SLÁMA, J., 1977: Mittelböhmen im frühen Mittelalter I. Katalog der Grabfunde. Praha.

SMOLÍK, J., 1884: Dvě česká pohřebiště z XI. století, PA XII, 13-26. 
SVĚTLÍK, I., 2017: Výsledky radiouhlíkového datování (Praha-Hrad, hrob IIIN199; Podlažice, hrob H04; Chrudim/Dašická ul., hrob 1; Žabonosy, hroby 32 a 65). Rkp. ulož. na pracovišti Pražský hrad, Oddělení archeologie středověku ARÚ AV ČR, Praha, v. v. i.

ŠOLTA, A., 1898: Nález starožitností v Chrudimi, PA XVIII, 538-539.

VOKOLEK, V., 1955: Chrudim. Nálezová zpráva čj. 1123/55, ulož. v Archivu ARÚ AV ČR, Praha, v. v. i.

WESTMAN, A. (ed.), 1994: Archaeological site manual. Museum of London. Archaeology service. 3rd edition. London.

ZÁPOTOCKÁ, M., 2004: Chrudim. Př́ispěvek ke vztahu české skupiny kultury s vypíchanou keramikou k malopolské skupině Samborzec-Opatów - Chrudim. Ein Beitrag zum Verhältnis der böhmischen Gruppe der Stichbandkeramik zur kleinpolnischer Gruppe Samborzec-Opatów, AR LVI, 3-55.

\section{Zusammenfassung}

\section{Ein frühmittelalterliches Gräberfeld in Chrudim, Dašická-Str.}

Im Jahr 2015 wurden am nördlichen Rand der Stadt Chrudim in der Dašická-Str. sechs Skelettgräber entdeckt (Abb. 1; 2). Die Gräber waren sehr flach und die Knochenreste waren durch den Einfluss postdepositärer Prozesse beträchtlich gestört (Abb. 3-6). Die Gräber waren in einer Reihe angeordnet. Die untersuchten Gräber verbindet eine minimale oder keine Eintiefung in den Untergrund. Bei der Herrichtung der Grabgruben wurden keine Steine benutzt. In den Gräbern H5 und H6 wurden Spuren von Holz registriert (Sarg?). Die Orientierung der Skelette ist gewöhnlich. Festgestellt wurde ein höheres Vorkommen eines eingeknickten Arms (insgesamt dreimal). Ebenso ist es mit zur Seite gedrehten Schädeln (ebenfalls dreimal). Anhand einer Radiokarbondatierung der Knochen aus Grab H1 (Labor HEKAL ATOMKI HAS in Debrecen, internationaler Code DebA) wurde eine jungburgwallzeitliche Datierung verifiziert. Die Ergebniskurve unterteilt die festgestellte Datierung in zwei Intervalle (Tab. 1; Abb. 7), und zwar 1022-1054 und 1078-1154 n. Chr. (Wahrscheinlichkeit 95\%).

Aus sechs Gräbern wurden die Gebeine einer Frau (?), von drei Männern und zwei unbestimmbaren Individuen gehoben. Alle waren älter als 30 Jahre, zwei erreichten gar das Greisenalter (ein Mann aus Grab H1 und eine Frau aus Grab H5). Die Männerknochen waren mittelrobust bis robust gebaut, das Frauenskelett zeichnete sich durch einen mittleren bis grazileren Körperbau aus. Die Entwicklung des Muskelreliefs entsprach dem Körperbau. An pathologischen Abweichungen am häufigsten vertreten waren Schädigungen des Gebisses - Karies, intravitale Verluste, Hypoplasie des Zahnschmelzes (Gräber H1, H4, H5, H6). Häufig waren auch degenerative produktive Veränderungen an der Wirbelsäule - Spondylose, Spondylarthrose (Grab H1, H2, H5, H6) und arthrotische Veränderungen auf den Gelenkflächen (Grab H1, H4, H6). Wir verzeichneten einen ausgeheilten Rippenbruch (Grab H2). Das Skelett des Mannes aus Grab H1 trug Spuren einer erhöhten körperlichen Anstrengung in Verbindung mit einem intensiveren Gang auf unebener Oberfläche und mit Belastung des Schultergürtels der oberen Extremitäten, was ein Beleg für die Ausübung landwirtschaftlicher Arbeiten (Ackerbau) oder für auf dem Rücken getragene Lasten sein kann. Die Periostitis an den Knochen der unteren Extremitäten kann die Folge eines mit der ausgeübten Tätigkeit verbundenen Traumas sein (Abb. 8). Die Charakteristik der an den Skeletten gemachten Befunde geben Auskunft über die nicht allzu gute Lebensqualität der untersuchten Individuen.

Das Gräberfeld befindet sich auf einer ausgeprägten Terrasse oberhalb des Flusses Chrudimka, der eine gewisse Wegebarriere zwischen diesem Gräberfeld und der Agglomeration des Chrudimer Burgwalles bildete. Auf der Terrasse befinden sich in nördlicher Nachbarschaft des Burgwalles in bis zu $1 \mathrm{~km}$ Entfernung vom Gräberfeld insgesamt drei Siedlungslagen mit jungburgwallzeitlichen Funden (Fundstellen 19, 20 und 45). Die Sichtbarkeitsanalyse des Gräberfeldes (Abb. 9) hat gezeigt, dass man bei einer Höhe von $2 \mathrm{~m}$ über dem Gelände auf Fundstelle 45 und teilweise auf Fundstelle 20 blicken kann. Weder das Areal des Burgwalles, noch Fundstelle 
19 konnten vom Gräberfeld aus gesehen werden. Daraus schließen wir, dass das Gräberfeld in der Dašická-Str. mit dem ländlichen Hinterland zusammenhängt, aus dem später die Siedlung Vestec entstand.

Im Kataster von Chrudim begegnet man einer größeren Anzahl an Gräberfeldern aus der Zeit bevor die hochmittelalterliche Stadt entstand (Abb. 1). Zwei Gräberfelder können wir als zu Kirchen gehörig charakterisieren (um die Mariä-Himmelfahrtskirche am Platz Resselovo náměstí und an der Hl. Kreuzkirche am südöstlichen Rand der frühmittelalterlichen Siedlungsagglomeration). Auf der Fläche des přemyslidischen Burgwalles waren die jungburgwallzeitlichen Gräber in der Filištínská-Str. Nr. 27/I und Nr. 35/I gestört, ferner in der Hradební-Str. Nr. 10/I. Das Gräberfeld des 12.-13. Jahrhunderts am Platz Školní náměstí liegt bereits in der Vorburg. Ein weiteres Gräberfeld befindet sich im Rahmen der Siedlungsagglomeration, die den Chrudimer Burgwall umschließt (Husova-Str., Areal der Fabrik Transporta, Topolská-Str., Jiráskova-Str. Nr. 428).

In den Regionen Chrudim und Pardubice wurden 48 Fundstellen mit Gräbern aus dem 9.-13. Jahrhundert erfasst. Zu Dorfgräberfeldern gehören nur 16 Fundstellen (Abb. 11). Die Zahl der bekannten Gräberfelder ist sehr niedrig und stellt weniger als ein Viertel (oder gar weniger als ein Zehntel) der mutmaßlichen Gräberfelder für den beobachteten Zeitraum dar. Durch die in der Region Chrudim seit den achtziger Jahren des vergangenen Jahrhunderts durchgeführten intensiven archäologischen Grabungen hat die Anzahl der Dorfgräberfelder - mit Ausnahme der Fundstelle Chrudim - Dašická-Str. - überraschenderweise jedoch nicht zugenommen. Der geringe Zuwachs an Fundstellen überrascht auch deshalb, weil in den letzten 25 Jahren eine größere Anzahl ausgedehnter Geländefreilegungen durchgeführt wurde. Bereits ab dem Jahr 1851 wurden Gräberfelder entdeckt und die Kenntnis von ihnen überliefert (Dašice, PA Frolík-Sigl 1995, 63), jedoch ist die Anzahl neuer Fundstellen und untersuchter Gräber ständig zurückgegangen (Tab. 2). Während den 167 Jahren, in denen man Funde registrierte, wurden 16 frühmittelalterliche Dorfgräberfelder (Reihengräber) bzw. genauer gesagt, ihre nicht groBen Torsos entdeckt. Die Anzahl der einzeln beschriebenen Gräber beträgt lediglich 44. Die größte Gruppe stellen durch Fügung der Umstände die zwei ältesten erfassten Gräberfelder dar (Dašice - 11 Gräber; Dražkovice - 16 Gräber), bei denen die näheren Fundumstände jedoch fehlen. Die nach 1950 erfassten Fundstellen bestehen aus Gräberfeldtorsos (Bezděkov - 4 Gräber; Rosice - 2 Gräber) oder nur aus Einzelgräbern (Čankovice; Chrudim, Topolská-Str.). Von der Gesamtanzahl der Gräber wurden lediglich 13 fachgerecht dokumentiert. Die beschriebene Situation betrachten wir als bedenklich, da uns aus der Region Chrudim bzw. Pardubice kein frühmittelalterliches Dorfgräberfeld bekannt ist, das (idealerweise) zur Gänze oder zumindest zu einem solchen Teil untersucht worden wäre, dass die gewonnenen Erkenntnisse statistisch ausgewertet werden könnten (mindestens einige Dutzend Gräber). Vergleicht man die in der Region Chrudim und Pardubice festgestellte Situation mit ganz Böhmen, stellt man dieselbe fatale Situation fest (Tab. 3). Es handelt sich also um eine langfristige Tendenz, für welche die Erklärung nicht ausreicht, dass es hier um einen Rückgang geht, der darauf zurückzuführen ist, dass sich die Gesamtanzahl an Gräberfeldern allmählich erschöpft. In der Region Chrudim und Pardubice ist es gelungen, ein dichtes Siedlungsnetz ab der Mittelburgwallzeit zu belegen, wobei uns für einen Teil davon jedoch kein Gräberfeld bekannt ist. Ebensowenig sind uns keine Skelettgräberfelder bekannt, die man in das 9. Jahrhundert datieren könnte (mit Ausnahme von Čankovice [?] - Abb. 10:2). Über die Gründe dafür können wir nur spekulieren. Einer von ihnen kann die starke Störung von Gräbern durch den Ackerbau sein, da die besser dokumentierten Gräber nur flach im Untergrund eingetieft waren. In dem Fall können auch viele Gräber auf Baustellen verschwunden sein, bei denen kein Archäologe zu den Abraumarbeiten hinzugezogen worden wurde.

Die Entdeckung des Gräberfeldes in der Dašická-Str. in Chrudim betrachten wir als wichtigen Beitrag dafür, Erkenntnisse über die Chrudimer Siedlungsagglomeration im Frühmittelalter zu gewinnen. Aus allgemein archäologischer Sicht, etwa bzgl. der Entwicklung der Fundgrundlage, wirft sie jedoch mehr Fragen auf, als dass sie Antworten gibt. 
Der vorliegende Beitrag entstand als Bestandteil des von der Förderagentur der Tschechischen Republik geförderten Projektes 14-36938G „Die mittelalterliche Population im Zentrum und auf dem Land. Archäologie, Bioarchäologie und Genetik auf den Gräberfeldern der Prager Burg, Mittel- und Ostböhmens“.

PhDr. Jan Frolík, CSc., Archeologický ústav AV ČR, Praha, v. v. i., Letenská 4, 11801 Praha 1, Česká republika,frolik@arup.cas.cz

PhDr. Jan Musil, Regionální muzeum v Chrudimi, Široká 86, 53701 Chrudim, Česká republika, musil@muzeumcr.cz

RNDr. Petra Stránská, Archeologický ústav AV ČR, Praha, v. v. i., Letenská 4, 11801 Praha 1, Česká republika,stranska@arup.cas.cz 
